\title{
DESAIN DSS (DECISION SUPPORT SYSTEM) MENGGUNAKAN METODE PROFILE MATCHING UNTUK PENENTUAN PENERIMA BEASISWA DI POLITEKNIK NEGERI SAMARINDA
}

\author{
Muchamad Zainul Rohman \\ Staf Pengajar Teknologi Informasi, Politeknik Negeri Samarinda \\ E-mail: zainul.mzr@gmail.com
}

\begin{abstract}
The scholarship selection process of Politeknik Negeri Samarinda are constraints on the decision-making process. This is because there is no objective method to determine quickly and precisely. To assist in the determination of the set someone worthy scholarship in this study will be design DSS (Decision Support System) with model of Multi-Criteria Decision Making. The method used is the method Profile Matching. Profile Matching methods have been able to select the best alternative from a number of alternatives, in this case meant that alternatives are eligible to receive scholarships based on the criteria specified. Research carried out by finding the weights for each sub-aspect, then carried ranking process that will determine the optimal alternative, the best students will be considered by decisionmakers to get a scholarship.
\end{abstract}

Keyword : Scholarship, Profile Matching, DSS (Decision Support System)

\begin{abstract}
Abstrak
Proses seleksi beasiswa di Politeknik Negeri Samarinda banyak terdapat kendala pada proses pengambilan keputusan. Hal ini dikarenakan belum ada metode objektifyang dapat memutuskan dengan cepat dan tepat. Untuk membantu penentuan dalam menetapkan seseorang yang layak menerima beasiswa maka dalam penelitian ini akan didesainkan DSS (Decision Support System) dengan model Multi Criteria Decision Making. Metode yang digunakan adalah metode Profile Matching. Metode Profile Matching dipilih karena mampu menyeleksi alternatif terbaik dari sejumlah alternatif, dalam hal ini alternatifyang dimaksudkan yaitu yang berhak menerima beasiswa berdasarkan kriteria-kriteria yang ditentukan. Penelitian dilakukan dengan mencari nilai bobot untuk setiap sub aspek, kemudian dilakukan proses perankingan yang akan menentukan alternatif yang optimal, yaitu mahasiswa terbaik yang akan dipertimbangkan oleh pengambil keputusan untuk mendapatkan beasiswa.
\end{abstract}

Kata Kunci : Beasiswa, Profile Matching, DSS (Decision Support System) 
Vol. 2, No. 1, Oktober 2014

\section{PENDAHULUAN}

Pada setiap periode ajaran baru, bagian kemahasiswaan menyeleksi mahasiswamahasiswa yang layak mendapatkan beasiswa. Proses penyeleksian beasiswa masih diproses secara manual sehingga membutuhkan ketelitian dan waktu yang cukup lama, karena data mahasiswa akan dibandingkan dengan kriteria beasiswa satu persatu. Dan permasalahan lain yang sering muncul dalam pemberian beasiswa ini adalah sulitnya menentukan mahasiswa yang benarbenar berhak menerima beasiswa karena keterbatasan kuota dan banyaknya kriteria yang digunakan untuk menentukan keputusan penerima beasiswa yang sesuai dengan yang diharapkan.

Didasari hal itulah untuk membantu penyeleksian penerima beasiswa maka dibutuhkan DSS (Decision Support Sistem) atau SPK (Sistem Pendukung Keputusan). DSS dimaksudkan untuk menjadi alat bantu bagi para pengambil keputusan untuk memperluas kapabilitas mereka, namun tidak untuk menggantikan penilaian mereka. DSS ditujukan untuk keputusan-keputusan yang memerlukan penilaian atau pada keputusankeputusan yang sama sekali tidak dapat didukung oleh algoritma. DSS merupakan sekumpulan prosedur berbasis model untuk data pemrosesan dan penilaian guna membantu para atasan mengambil keputusan dan untuk kesuksesan sistem ini haruslah sederhana, cepat, mudah dikontrol, adiptif, lengkap dengan isu-isu penting, dan mudah untuk berkomunikasi (Little, 1970).

Salah satu metode sistem pendukung keputusan adalah Metode Profile Matching. Metode ini cukup efektif dalam menyederhanakan dan mempercepat proses pengambilan keputusan dengan memecahkan persoalan tersebut ke dalam bagianbagiannya. Metode ini juga mampu menyeleksi alternatif terbaik dari sejumlah alternatif. Penelitian dilakukan dengan menentukan aspek dan sub aspek berserta mencari nilai bobot untuk setiap sub aspek, mencari GAP antara profile dengan keadaan data dari mahasiswa dengan menggunakan metode ini ditentukan presentasi kedua unsur aspek dan ditotal kemudian dilakukan proses perankingan yang akan menentukan alternatif yang optimal, yaitu mahasiswa yang berhak mendapatkan beasiswa.

Metode perangkingan diatas diharapkan akan memberikan penilaian yang lebih tepat. Hal ini dikarenakan penilaian didasarkan pada kriteria dan bobot yang sudah ditentukan terlebih dahulu. Sebagai konsekuensinya penentuan penerima beasiswa lebih akurat.

\section{TINJAUAN PUSTAKA}

\subsection{Kajian Ilmiah}

Profile matching merupakan suatu proses yang sangat penting dalam manajemen sumber daya manusia (SDM) dimana terlebih dahulu ditentukan kompetensi (kemampuan) yang diperlukan. Dalam proses profile matching secara garis besar merupakan proses membandingkan antara kompetensi seorang dosen ke dalam kompetensi kampus sehingga dapat diketahui perbedaan kompetensinya (disebut juga gap). Semakin kecil gap yang dihasilkan maka bobot nilainya semakin besar.(Joko Kuswanto, Ema Utami, 2011).

\subsection{DSS / SPK}

SPK (Sistem Pendukung Keputusan) adalah sistem berbasis komputer interaktif, yang membantu para pengambil keputusan untuk menggunakan data dan berbagai model untuk memecahkan masalah-masalah tidak terstruktur (Turban dkk, 2005).

$$
\text { Menurut Kusrini }
$$

mendefinisikan sistem pendukung keputusan merupakan sistem informasi interaktif yang menyediakan informasi, pemodelan dan manipulasi data. Sistem itu digunakan untuk membantu pengambilan keputusan dalam situasi yang semiterstruktur dan situasi tidak terstruktur, dimana tak seorang pun tahu secara pasti bagaimana keputusan seharusnya dibuat. 
Muchamad Zainul Rohman, Desain DSS (Decision Support System) Menggunakan Metode Profile Matching Untuk Penentuan Penerima Beasiswa Di Politeknik Negeri Samarinda

Senada dengan pakar lainnya Turban dkk (2005) mendefinisikan sistem pendukung keputusan sebagai sekumpulan prosedur berbasis model untuk data pemrosesan dan penilaian guna membantu para manajer mengambil keputusan.

Dari beberapa definisi diatas dapat dikatakan bahwa sistem pendukung keputusan adalah suatu sistem informasi spesifik yang ditujukan untuk membantu dalam pengambilan keputusan berkaitan dengan persoalan yang bersifat semi terstruktur.

\subsection{Tujuan Sistem Pendukung Keputusan}

Menurut Kusrini (2007), tujuan sistem pendukung keputusan adalah:

- Membantu manajer dalam pe ngambilan keputusan atas masalah semiterstruktur.

- Memberikan dukungan atas pertimbangan manajer dan bukannya dimaksudkan untuk mengganti fungsi manajer.

- Meningkatkan efektivitas keputusan yang diambil lebih dari perbaikan efisiensinya.

- Kecepatan komputasi. Komputer memungkinkan para pengambil keputusan untuk melakukan banyak komputasi secara cepat dengan biaya rendah.

- Peningkatan produktifitas. Membangun satu kelompok pengambil keputusan, terutama para pakar bisa sangat mahal. Pendukung terkomputerisasi bisa mengurangi ukuran kelompok dan memungkinkan para anggotanya untuk berada di berbagai lokasi yang berbedabeda (menghemat biaya perjalanan).

- Dukungan kualitas. Komputer bisa meningkatkan kualitas keputusan yang dibuat.

- Berdaya saing.

- Mengatasi keterbatasan kognitif dalam pemrosesan dan penyimpanan.

\subsection{Metode Profile Matching}

Metode profile matching atau pencocokan profil adalah metode yang sering sebagai mekanisme dalam pengambilan keputusan dengan mengasumsikan bahwa terdapat tingkat variabel prediktor yang ideal yang harus dipenuhi oleh subyek yang diteliti, bukannya tingkat minimal yang harus dipenuhi atau dilewati (Kusrini, 2007).

Dalam proses profile matching secara garis besar merupakan proses membandingkan antara nilai data aktual dari suatu profile yang akan dinilai dengan nilai profil yang diharapkan, sehingga dapat diketahui perbedaan kompetensinya (disebut juga gap), semakin kecil gap yang dihasilkan maka bobot nilainya semakin besar yang berarti memiliki peluang lebih besar untuk direkomendasikan untuk terpilih dalam hal ini sebagai penerima beasiswa. Berikut adalah beberapa tahapan dan perumusan perhitungan dengan metode profile matching (Kusrini,2007) :

\section{KERANGKA PENELITIAN}

KONSEP

Diagram alir kerangka konsep penelitian ditunjukan dalam gambar berikut. 


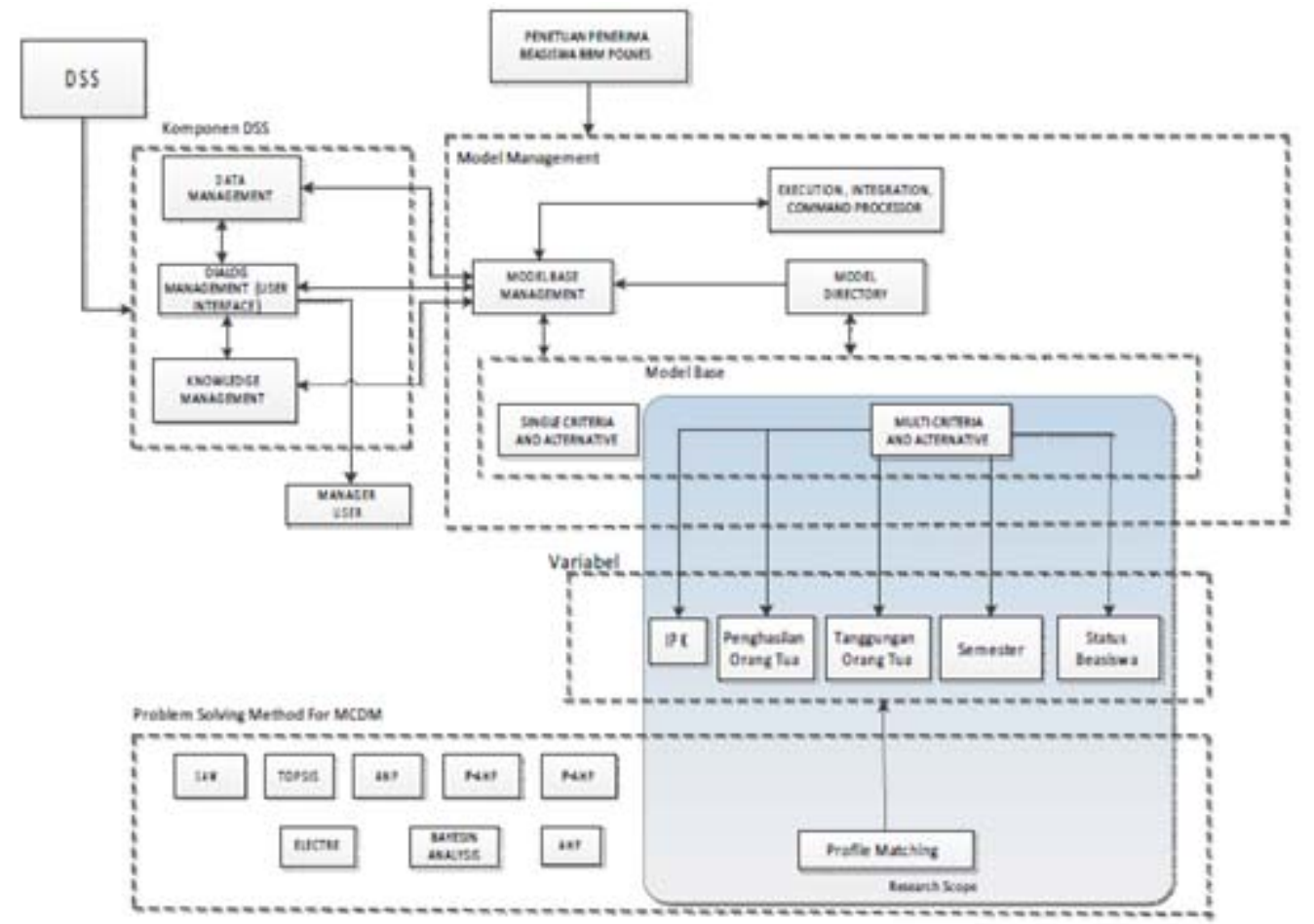

Gambar 1. Diagram Alir Kerangka Konsep Penelitian

DSS memiliki beberapa komponen dasar seperti Knowledge Management, Data Management, Model Management, Dialog Management.

Komponen Knowledge Management merupakan pendukung semua komponen lain atau bertindak langsung sebagai suatu komponen independen. Komponen ini memberikan intelegensi atau pengetahuan tentang DSS untuk memperbesar pengetahuan sipengambil keputusan.

Data Management merupakan suatu komponen yang memasukkan satu dataBest yang berisi data yang relevan tentang aspekaspek penilaian kriteria.
Dialog Management merupakan komponen yang menyediakan interface antara user dengan sistem DSS untuk saling berinteraksi. Dalam hal ini user merupakan bagian yang dipertimbangkan dari sistem.

Model Management merupakan paket perangkat lunak yang memasukan suatu model atau metode perhitungan yang memberikan kapabilitas analitik untuk mempermudah proses sistem keputusan, metode yang digunakan untuk proses perhitungan adalah metode Profile Matching. 
Muchamad Zainul Rohman, Desain DSS (Decision Support System) Menggunakan Metode Profile Matching Untuk Penentuan Penerima Beasiswa Di Politeknik Negeri Samarinda

\section{METODOLOGI PENELITIAN}

Diagram alir metodologi penelitian ditunjukan dalam gambar berikut.

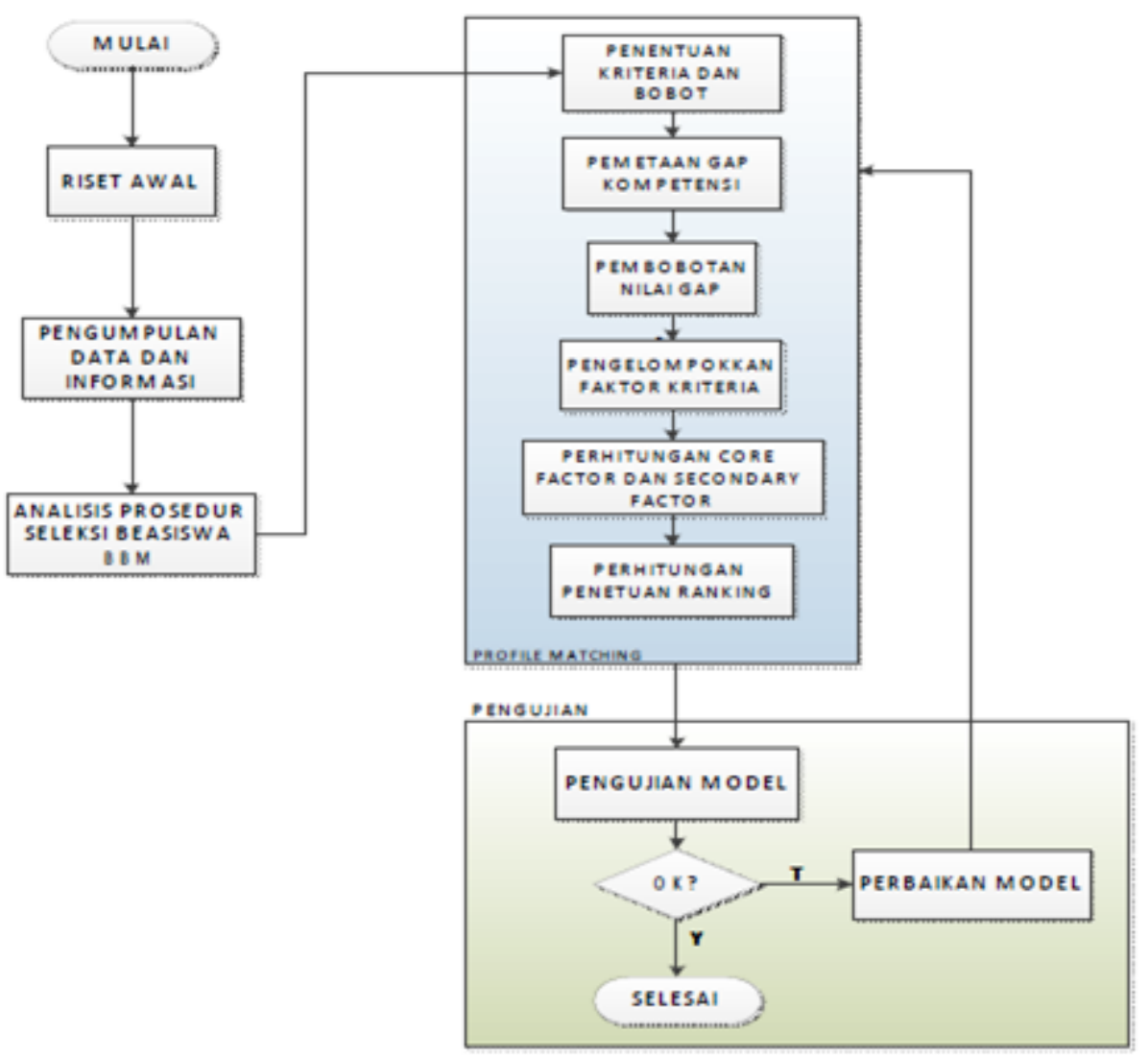

Gambar 2. Diagram Alir Metodologi Penelitian

Setelah data dan informasi sudah diketahui selanjutnya pemrosesan perhitungan menggunakan metode profile matching. Langkah-langkah pada metode profile matching yaitu :

a. Penentuan Kriteria \& Bobot

Kriteria atau parameter yang ditetapkan dalam penelitian ini adalah sesuai dengan yang ditentukan oleh pihak akademik POLNES sub bagian kemahasiswaan sesuai dengan yang tertulis di buku panduan akademik.

b. Pemetaan Gap Kompetensi

Gap yang dimaksud disini adalah perbedaan antara profile mahasiswa pemohon beasiswa dengan profil beasiswa.

c. Pembobotan Nilai Gap 46 Setelah diperoleh gap pada masing- masing mahasiswa calon penerima beasiswa, setiap profil mahasiswa diberi bobot nilai.

d. Pengelompokan Faktor Kriteria Setelah menentukan bobot nilai gap selanjutnya yaitu mengelompokan kriteria menjadi 2 kelompok, yaitu kelompok Core Factor dan Secondary Factor.

e. Perhitungan Core Factor dan Secondary Factor

f. Perhitungan Penentuan Rangking.

Hasil akhir dari proses profile matching adalah rangking dari mahasiswa calon penerima beasiswa. Penentuan rangking mengacu pada hasil perhitungan tertentu. Dalam penelitian ini perhitungan 
Vol. 2, No. 1, Oktober 2014

rangking dengan menghitung nilai total berdasarkan presentase dari core factor dan secondary factor yang diperkirakan berpengaruh terhadap kinerja tiap-tiap profil. Pada penilaian beasiswa ini diasumsikan nilai core factor adalah $90 \%$ dan secondary factor adalah $10 \%$. Contoh perhitungan bisa dilihat pada rumus di bawah ini :

$N=(X) \% * N C F(p, i, t)+(X) \% *$ $N S F(s, s b)$

Keterangan :

$\mathrm{N}=$ Nilai TotalTiap Aspek/Kriteria

NCF = Nilai Core Factor

NSF = Nilai Secondary Factor

$(\mathrm{X}) \%=$ Jumlah persentase yang diinputkan dengan ketentuan nilai core factor $90 \%$ dan secondary factor $10 \%$.

\section{PEMBAHASAN}

FLOW CHART PROGRAM UTAMA PROFILE MATCHING (DESAIN DSS)

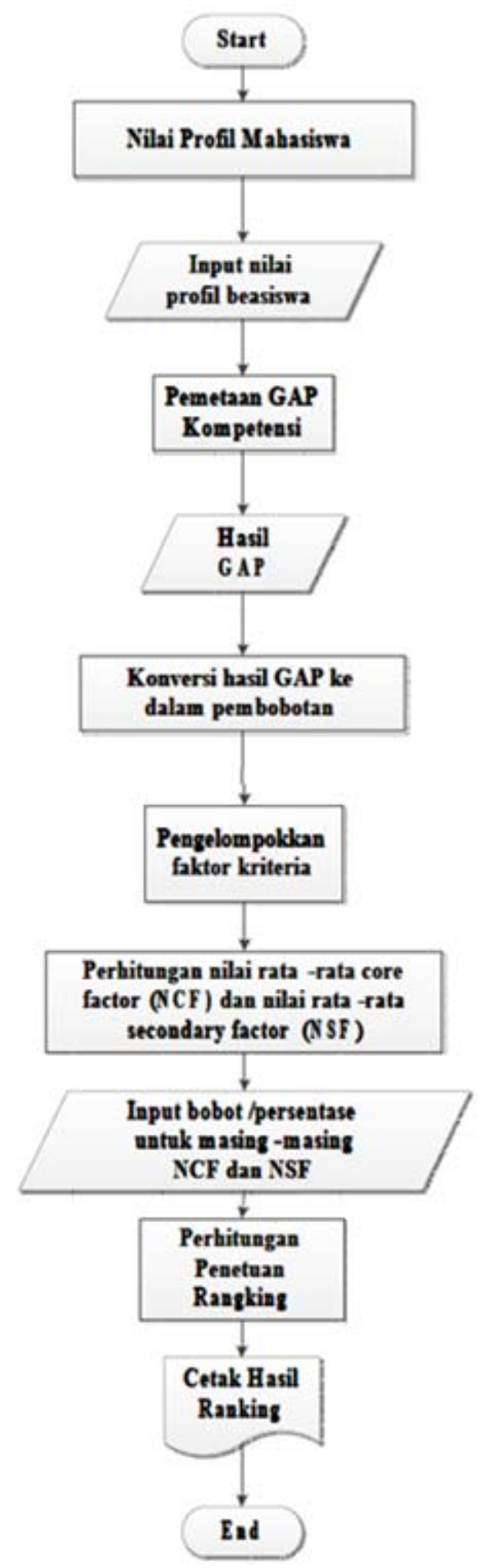

Gambar 3. Flow Chart Program Utama (Desain DSS) 
Muchamad Zainul Rohman, Desain DSS (Decision Support System) Menggunakan Metode Profile Matching Untuk Penentuan Penerima Beasiswa Di Politeknik Negeri Samarinda

Dari gambar 3 dapat dilihat bahwa pada proses awal adalah memproses nilai profil mahasiswa, setelah itu menginputkan nilai profil beasiswa yang telah ditentukan. Setelah nilai profil mahasiswa dan profil beasiswa telah didapatkan maka proses selanjutnya adalah melakukan pemetaan gap kompetensi/mencari nilai gap dengan cara mencari selisih antara nilai profil mahasiswa dengan nilai profil beasiswa. Setelah nilai gap didapatkan selanjutnya melakukan konversi hasil gap ke dalam pembobotan gap. Selanjutnya melakukan pengelompokan faktor kriteria setelah itu melakukan proses mencari nilai rata-rata core factor (NCF) dan nilai rata-rata secondary factor (NSF). Setelah nilai rata-rata didapatkan selanjutnya menginputkan bobot / prersentase untuk masing-masing NCF dan NSF.
Setelah nilai rata-rata dan nilai persentase core factor dan secondary factor telah didapatkan maka proses selanjutnya adalah mencari nilai akhir untuk penentuan rangking dengan cara mengalikan nilai persentase core factor dengan nilai rata-rata core factor dan mengalikan nilai persentase secondary factor dengan nilai rata-rata secondary factor. Setalah hasil perkalian didapatkan lalu hasil tersebut dijumlahkan. Setelah nilai akhir didapatkan maka nilai tersebut dapat dirangking untuk melihat mahasiswa yang direkomendasikan untuk menerima beasiswa.

\section{a. Flowchart Proses Nilai Profil Mahasiswa}

Pada sub bab ini akan

dijelaskan proses pada Gambar 4 yaitu proses nilai profil mahasiswa.

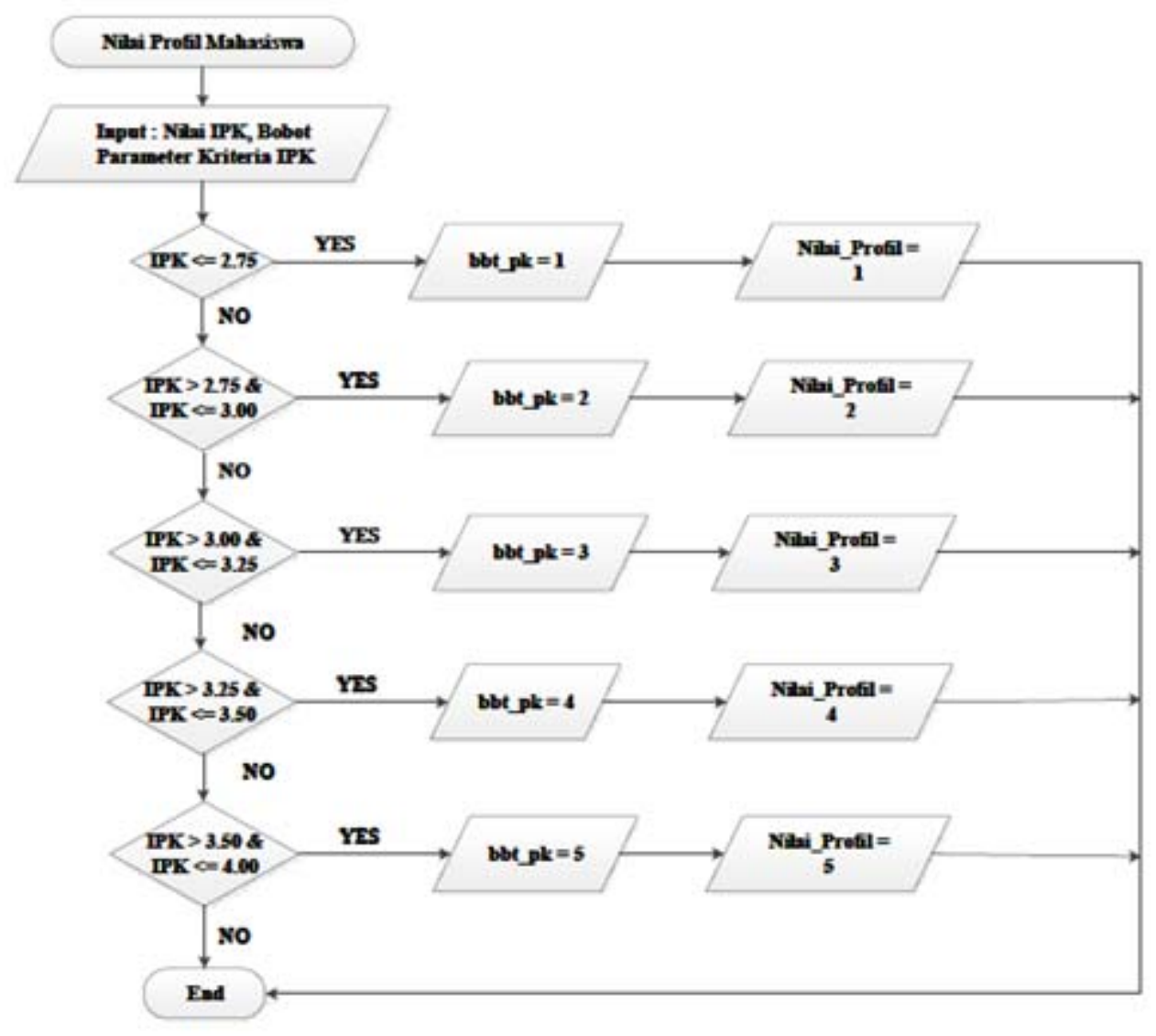

Gambar 4. Flow Chart Proses Nilai Profil Mahasiswa Kriteria IPK 
Vol. 2, No. 1, Oktober 2014

Pada Gambar 4 dapat dilihat bahwa proses awal yang dilakukan adalah menginputkan nilai IPK dan nilai bobot dari parameter Kriteria IPK. Selanjutnya terdapat proses kondisi dimana jika IPK mahasiswa kurang dari sama dengan 2.75 maka bobotnya adalah 1 sehingga nilai profil mahasiswa untuk kriteria IPK adalah 1, jika IPK mahasiswa lebih dari 2.75 dan kurang dari sama dengan 3.00 maka bobotnya adalah 2 sehingga nilai profil mahasiswa untuk kriteria IPK adalah 2, jika IPK mahasiswa lebih dari 3.00 dan kurang dari sama dengan 3.25 maka bobotnya adalah 3 sehingga nilai profil mahasiswa untuk kriteria IPK adalah 3, jika IPK mahasiswa lebih dari 3.25 dan kurang dari sama dengan 3.50 maka bobotnya adalah 4 sehingga nilai profil mahasiswa untuk kriteria IPK adalah 4, dan jika IPK mahasiswa lebih dari 3.50 dan kurang dari sama dengan 4.00 maka bobotnya adalah 5 sehingga nilai profil mahasiswa untuk kriteria IPK adalah 5.

\section{b. Flowchart Proses Konversi Hasil GAP kedalam Pembobotan}

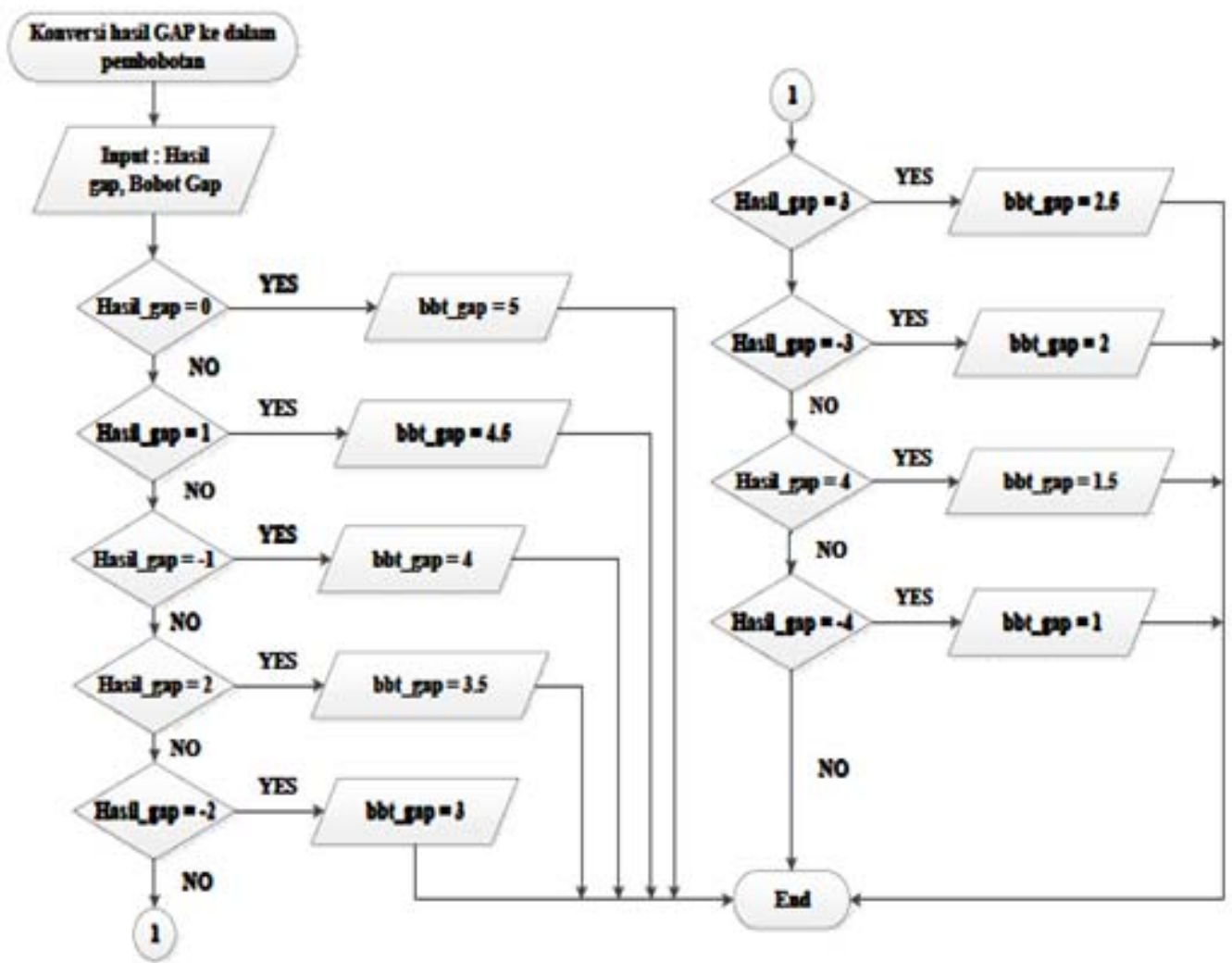

Gambar 5. Flow Chart Proses Konversi Hasil GAP kedalam Pembobotan 
Muchamad Zainul Rohman, Desain DSS (Decision Support System) Menggunakan Metode Profile Matching Untuk Penentuan Penerima Beasiswa Di Politeknik Negeri Samarinda

Pada Gambar 5 dapat dilihat bahwa proses awal yang dilakukan adalah menginputkan hasil gap dan nilai bobot gap. Selanjutnya terdapat proses kondisi dimana jika hasil gap (selisih) = 0 maka bobotnya adalah 5 sehingga nilai profil mahasiswa adalah 5 , jika hasil gap = 1 maka bobotnya adalah 4.5 sehingga nilai profil mahasiswa adalah 4.5, jika hasil gap $=-1$ maka bobotnya adalah 4 sehingga nilai profil mahasiswa adalah 4, jika hasil gap = 2 maka bobotnya adalah 3.5 sehingga nilai profil mahasiswa adalah 3.5, jika hasil gap $=-2$ maka bobotnya adalah 3 sehingga nilai profil mahasiswa adalah 3 , jika hasil gap = 3 maka bobotnya adalah 2.5 sehingga nilai profil mahasiswa adalah 2.5, jika hasil gap $=-3$ maka bobotnya adalah 2 sehingga nilai profil mahasiswa adalah 2, jika hasil gap = 4 maka bobotnya adalah 1.5 sehingga nilai profil mahasiswa adalah 1.5, jika hasil gap $=-4$ maka bobotnya adalah 1 sehingga nilai profil mahasiswa adalah 1 .

\section{c. Flowchart Proses Perhitungan Nilai Rata-Rata Core Factor dan Secondary Factor}

Pada sub bab ini akan dijelaskan proses perhitungan nilai rata-rata core factor dan nilai rata-rata secondary factor, gambar flow chart untuk proses tersebut ditunjukkan pada Gambar 6.

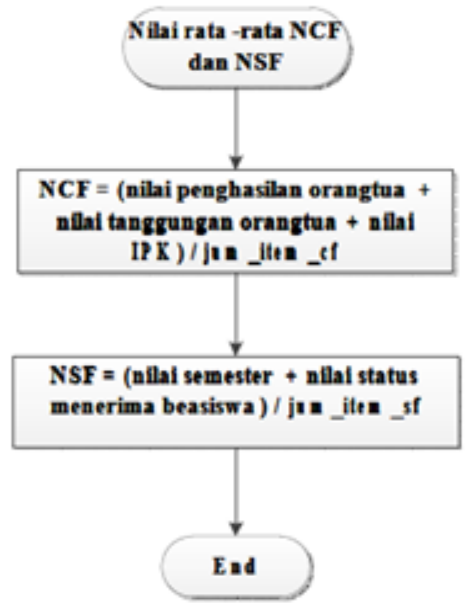

Gambar 6. Flow Chart Proses Nilai Rata-Rata Core Factor dan Secondary Factor
Dalam proses mencari nilai rata-rata core factor adalah menjumlahkan nilai profil mahasiswa untuk kriteria penghasilan orangtua, nilai profil mahasiswa untuk kriteria tanggungan orangtua, dan nilai profil mahasiswa untuk kriteria IPK setelah itu dibagi dengan banyaknya jumlah item core factor.

Untuk proses mencari nilai rata-rata secondary factor adalah menjumlahkan nilai profil mahasiswa untuk kriteria semester dan nilai profil mahasiswa untuk kriteria status menerima beasiswa setelah itu dibagi dengan banyaknya jumlah item secondary factor.

\section{KESIMPULAN DAN SARAN}

\subsection{Kesimpulan}

Berdasarkan pengujian, pengamatan dan desain yang telah dilakukan pada proses seleksi beasiswa menggunakan metode profile matching, maka dapat diambil kesimpulan sebagai berikut :

1. Metode profile matching dapat digunakan pada proses seleksi beasiswa karna pada proses perhitungannya telah ditentukan bobot pada masing-masing kriteria dan bobot pada masing-masing parameter kriteria sehingga dalam penentuan mahasiswa penerima beasiswa menjadi lebih objektif.

2. Metode profile matching dapat memberikan rekomendasi berupa mahasiswa yang berhak mendapatkan beasiswa sesuai dengan standar nilai kriteria yang diharapkan.

\subsection{Saran}

Saran yang dapat diberikan untuk pengembangan penelitian ini lebih lanjut maka diharapkan hasil dari penelitian ini dapat diimplementasikan ke dalam software aplikasi sehingga akan lebih mempermudah penyeleksi dalam mengambil keputusan. 


\section{DAFTAR PUSTAKA}

Kusrini. 2007. Konsep dan Aplikasi Sistem Pendukung Keputusan. Andi Offset. Yogyakarta. Kuswanto, Joko dan Ema Utami. 2011. Sistem Pendukung Keputusan Penilaian Kinerja Dosen(Studi Kasus Pada Universitas Baturaja, Oku, Sumatera Selatan. Jurnal TeknologiInformasi . Vol VI, No. 17.

Muchsam, Yoki, Falahah dan Galih Irianto Saputro. 2011. Penerapan GAP Analysis Pada Pengembangan Sistem Pendukung Keputusan Penilain Kinerja Karyawan (Studi Kasus PT. XYZ). Yogyakarta.Seminar Nasional Aplikasi TeknologiInformasi.

Turban, Efraim dkk. 2005. Decision Support Sistem and Intelligent Sistem. jilid 1. Andi Offset. Yogyakarta. 